Florida International University FIU Digital Commons

4-7-2010

\title{
Guantanamo: A Working-Class History Between Empire and Revolution
}

Cuban Research Institute, Florida International University

Follow this and additional works at: https://digitalcommons.fiu.edu/cri_events

Part of the Latin American Studies Commons

\section{Recommended Citation}

Cuban Research Institute, Florida International University, "Guantanamo: A Working-Class History Between Empire and Revolution" (2010). Cuban Research Institute Events. 176.

https://digitalcommons.fiu.edu/cri_events/176

This work is brought to you for free and open access by the Cuban Research Institute at FIU Digital Commons. It has been accepted for inclusion in Cuban Research Institute Events by an authorized administrator of FIU Digital Commons. For more information, please contact dcc@fiu.edu. 


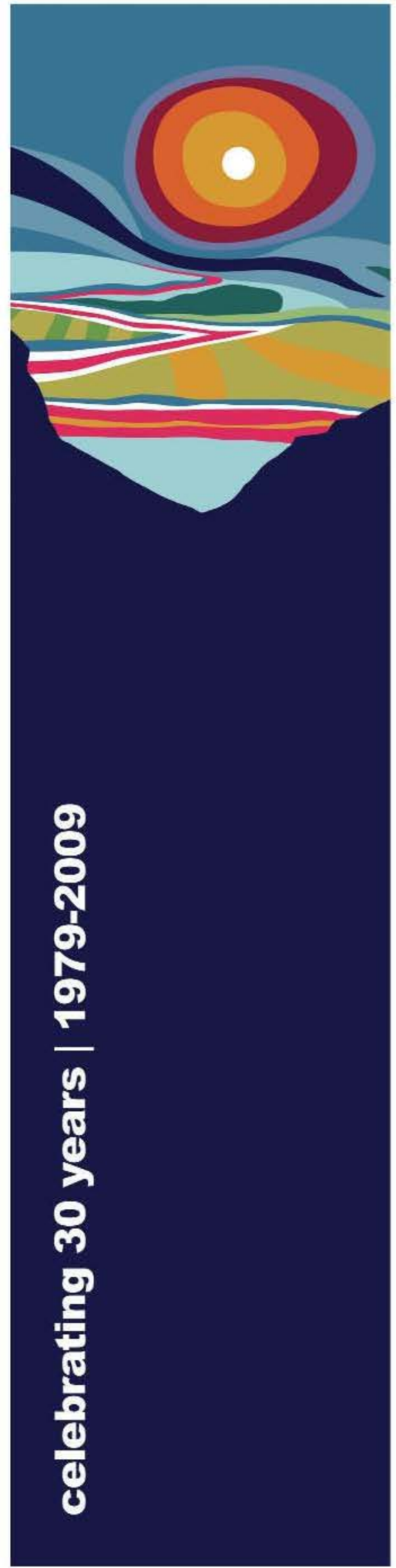

Cordially invite you to the book presentation of

Guantánamo: A Working-Class History Between Empire and Revolution

by

Jana K. Lipman, Ph.D. Assistant Professor of History, Tulane University

\section{Wednesday, April 7, 2010 | 6:30 p.m. Books \& Books 265 Aragon Avenue Coral Gables, Florida}

Jana K. Lipman holds a Ph.D. from Yale University (2006). She specializes in the 20th century political and social histories of the United States, Cuba and Vietnam, particularly as they relate to foreign relations. Guantánamo: A Working-Class History Between Empire and Revolution shows that more than a U.S. naval base and prison in Cuba, Guantánamo is a town that has required more than soldiers and sailors - it has required workers. This revealing story of the women and men who worked on the U.S. naval base in Guantánamo Bay tells the story of U.S.-Cuban relations from a new perspective. At the same time, it shows how neocolonialism, empire, and revolution transformed the lives of everyday people. Drawing from rich oral histories and little-explored Cuban archives, Jana K. Lipman analyzes how the Cold War and the Cuban revolution made the naval base a place devoid of law and accountability.

Book is available for purchase at the FIU Bookstore and Books \& Books. Event is free and open to the public. For information and to RSVP call (305) 348-1991 or Books \& Books at (305) 442-4408.

Co-sponsored by the Latin American and Caribbean Center, the Cuban Research Institute, Maloka (LACC Graduate Student Association) with support from FIU CSO, FIU Law, the African and African Diaspora Studies Program, the Department of History Graduate Student Association with support from FIU CSO, the Department of History, the Department of Politics and International Relations, the Asian Studies Program, and Books \& Books. 